\title{
SLC44A1 Gene
}

National Cancer Institute

\section{Source}

National Cancer Institute. SLC44A1 Gene. NCI Thesaurus. Code C112081.

This gene plays a role in choline transport. 